J. Product. \& Dev., 24(4): 705-725(2019)

\title{
RESPONSE OF PHYSICAL AND PHYSIO-CHEMICAL ATTRIBUTES IN GUAVA FRUITS TO GUM ARABIC AND CALCIUM CHLORIDE TREATMENTS UNDER COLD STORAGE
}

\author{
Usama K. El-Abbasy ${ }^{1}$; Ahmed F. Abd El-khalek'; Hanafey F Maswada and \\ Asmaa N. Abou-Ismail ${ }^{*}$ \\ ${ }^{1}$ Horticulture Department, Faculty of Agriculture, Tanta University, 31527. \\ Egypt. \\ ${ }^{2}$ AgriculturalBotany Department, Faculty of Agriculture, Tanta University, \\ 31527. Egypt.*Asmaanadeer92@gmail.com
}

\section{ABSTRACT}

This experiment was conducted during 2016 and 2017 seasons in Post-harvest Lab. Hort. Dept., Fac. Agric., Tanat University., Egypt to study the effects of Gum Arabic and /or calcium chloride on postharvest storage life and fruit quality of 'Maamoura' guavas during two consecutive seasons (2016 and 2017). Guava fruits were dipped for $3 \mathrm{~min}$. into distilled water (control), Gum Arabic (GA, 10\%), $\mathrm{CaCl}_{2}\left(\mathrm{CC}_{1}, 2 \%\right)$, $C C_{2}(4 \%), G A(10 \%)+C C_{1}(2 \%)$ and $G A(10 \%)+C C_{2}(4 \%)$. Treated and control fruits were stored at $7 \pm 1{ }^{\circ} \mathrm{C}$ and $90 \pm 5 \%$ relative humidity (RH) for 24 days. The changes in physical and chemical characteristics of guava fruits were determined every eight days of cold storage.

Results of this study indicated that, all postharvest treatments reduced the deterioration in physical and chemical characteristics compared to untreated fruits (control). In addition, combined treatments of $10 \%$ of Gum Arabic with 2 or $4 \%$ of calcium chloride were superior to individual treatments. These treatments minimized the fruit weight loss and decay percentages and maximized fruit marketable percentage as well as maintained fruit firmness and visual appearance score during storage. Moreover, these applications delayed color development by retained total chlorophyll content as well as maintained fruit contents in ascorbic acid and total acidity and reduced the total soluble solids and total soluble solids/acid acidity ratio during cold storage period. Ultimately, these applications increase total phenolic and antioxidant contents; also, 
prolonged shelf life period of guava fruits at $\left(25 \pm 2{ }^{\circ} \mathrm{C}\right.$ and $\left.65 \pm 5 \% \mathrm{RH}\right)$ after end of cold storage period (24 days) as compared to control.

Conclusively, combined treatments of $10 \%$ of Gum Arabic with 2 or $4 \%$ of calcium chloride reduced the deterioration in physical and chemical characteristics compared to untreated fruits (control).

Keywords: Guava fruits, Gum Arabc, calcium chloride, postharvest, storability.

\section{INTRODUCTION}

Guava is one of the commercially important fruit in more than 50 countries. In 2017 the world total area harvested was 3.4 million Hectares produced about 23.8 million ton of Guava fruits. In the same year, the total area harvested in Egypt was 3556 hectares produced about 27922 tons of Guava fruit (FAO Statistics, 2017). Guava fruit is a rich source of dietary fibers, different vitamins particularly vitamin $\mathrm{C}$ and some important minerals $(\mathrm{P}, \mathrm{K}, \mathrm{Ca}$ and $\mathrm{Fe}$ ) (Hui, 2004). Moreover, guavas used in a wide range of food products like juice concentrates, paste, puree, squash, jams, jellies and candies. Guava fruit has a rapid softening rate due to its climacteric nature and higher metabolic activities, which reduces in storage life (Jilani et al., 2010). It is the immense need of time to develop efficient strategies to overcome consumer demand and enhance quality of fruits during the entire storage duration to improve the storage life. Currently there are various techniques to improve postharvest storage life of guava fruit (Falcao-Rodrigues et al., 2007).

Edible coating is one of the practical strategies for increasing storage life of the guavas. Edible coating got attention of the scientists due to its beneficial effects on general appearance, senescence and biofilms (Rojas-Grau et al., 2009). Gum Arabic(GA) is a polysaccharide naturally secreted from stems and branches of Acacia species and is composed of galactose, rhamnose, arabinose and glucoronic acid. Postharvest coated apples with GA significantly reduced decay incidence, weight loss percentage, softness and colour development as well as maintained internal quality during cold storage compared to uncoated fruits (El-Anany et al., 2009). Moreover, 10\% GA coating alone or combined with lemongrass oil or cinnamon oil controlled anthracnose and maintained quality of banana and papaya fruits (Maqbool et al., 2011). Pre-storage treatment of mangoes with GA at $10 \%$ alone or incorporated with calcium chloride at $3 \%$ 
effectively reduced decay incidence, weight loss, colour changes and soluble solid content as well as efficiently maintained high firmness, ascorbic acid, titratable acidity in mango fruit (Khaliq et al., 2015). Additionally, GA coating effectively maintained total antioxidant and total phenolic content in mangoes (Khaliq et al., 2016) and oranges (Abd El-khalek, 2018).

Calcium has been used in the fruits and vegetables sector for whole and fresh-cut commodities as preservative and firming agent (Chardonnet et al., 2003). Calcium ions ensure higher cohesion of the cell wall and thus decrease the senescence and ripening of fruits (Laster and Grusak, 2004). Additionally, calcium based salts enhance structure of cell wall by creating bond between calcium and pectin (Akhtar et al., 2010). Calcium salts are extensively used for maintaining postharvest fruit quality. Therefore, the objective of the present investigation was to evaluate the impact of postharvest applications of Gum Arabic, calcium chloride and their combinations on maintaining the quality attributes and extending life of 'Maamoura' guava fruits during cold storage at $7 \pm 1^{\circ} \mathrm{C}$ and $90 \pm 5 \% \mathrm{RH}$.

\section{MATERIALS AND METHODS}

\section{Fruit material}

Guava fruits were harvested from a private orchard (grown in Metoubes, Kafr El-Sheikh Governorate, Egypt (latitude, 31 ${ }^{\circ} 29^{\prime} \mathrm{N}$; longitude, 3052' E) during 2016 and 2017 seasons) at maturity stage (yellowish green) in the second week of August according to Mercado-Silva et al. (1998) from almost similar trees and guavas apparently uniform in size and free of visible symptoms of infection.

\section{Postharvest treatments and storage}

In both experimental sessions, 'Maamoura' guava fruits were transferred to the Horticulture laboratory, Tanta University, immediately after harvesting (during 2 hours) at ambient temperature $\left(25^{\circ} \mathrm{C}\right)$ in plastic boxes $(15 \mathrm{~kg}$ capacity). On arrival, the fruits were cleaned, sorted, graded and the detective fruits including wounded and other disorders were excluded. The sound fruits at the same maturity stage were washed with $0.01 \%$ sodium hypochlorite solution for 2 min and then air dried at room temperature until visible moisture on fruit surfaces disappeared completely. 
A total of 1080 clean sound fruits were selected and randomly divided into six treatments with three replicates (60 fruit / replicate) and expressed as control (CK), $10 \%$ of Gum Arabic (GA), $2 \%$ of calcium chloride $\left(\mathrm{CC}_{1}\right), 4 \%$ of calcium chloride $\left(\mathrm{CC}_{2}\right), \mathrm{GA}+\mathrm{CC}_{1}$ and $\mathrm{GA}+\mathrm{CC}_{2}$. All guava fruits were dipped in the treatment solutions for $3 \mathrm{~min}$. After dipping treatments, the fruits were allowed to dry for $30 \mathrm{~min}$ at room temperature by an electric fan. After that, the fruits in each treatment were packed in foam plates covered with perforated polyethylene sheets with a thickness of $0.04 \mathrm{~mm}$ and then packaged in cardboard boxes with dimensions of $45 \times 35 \times 10 \mathrm{~cm}$. All experimental boxes were stored at $7 \pm 1^{\circ} \mathrm{C}$ and $90 \pm 5 \% \mathrm{RH}$ for 24 days. Fruit physical and chemical characteristics were examined at harvest time and then every eight days intervals of the cold storage period.

\section{Fruit physical attributes}

Fruit weight loss percentage was calculated by the following formula: [(fruit weight before storage - fruit weight after each period of cold storage) / fruit weight before storage] $\times 100$.

Fruit decay percentage was recorded every eight days of cold storage by counting the number of decayed fruits due to fungus or any microorganisms infection and calculated as a percentage of the initial number of stored fruits using the following equation: (number of decayed fruits at specified storage period / initial number of stored fruit) $\times 100$.

Marketable fruit percentage was calculated by the following formula: (weight of sound fruits at specified storage period / initial weight of fruits) $\times 100$.

Visual appearance of fruit was measured by a rating system, fruit scored: very $\operatorname{good}=9, \operatorname{good}=7$, acceptable $=5$, unacceptable $=3$ and poor $=1$

Fruit firmness was measured in three guava fruits per replicate at two equatorial opposite sites to determine the penetration force by using a hand-held fruit firmness tester (FT-327, Italy) equipped with an $8 \mathrm{~mm}$ cylindrical stainless steel plunger tip (Watkins and Harman, 1981). Two readings were taken on the flesh of each fruit after peeling. The firmness value was expressed in terms of kilogram force (kgf) and data was calculated as Newton (N).

\section{Fruit physio-biochemical attributes}

Chlorophyll and carotenoid contents in the pulp of guavas (three replicates) were spectrophotometrically determined according to the method of Wellburn (1994). After each of cold storage period, fifteen guava fruits from 
each treatment (three replicates) were extracted by crushing the pulp of fruits, then the juice strained through a muslin cloth and used for measuring internal fruit quality according to AOAC (2005) as follow:

For ascorbic acid analysis, samples of fruit juice were used, oxalic acid solution was added to each sample and titrated with 2,6-dichlorophenolindophenol dye solution and expressed as a milligram of ascorbic acid and was calculated as $\mathrm{mg} / 100 \mathrm{ml}$ of the juice.

Fruit juice total soluble solids content (TSS) was measured using a hand refractometer, 0-32 scale (ATAGO N-1 $1_{\mathrm{E}}$, Japan) and expressed in ${ }^{\circ}$ Brix after making the temperature correction at $20^{\circ} \mathrm{C}$.

For juice titratable acidity (TA), aliquot of fruit juice was taken and titrated against $0.1 \mathrm{~N} \mathrm{NaOH}$ in the presence of phenolphthalein as an indicator to the end point and expressed as a percentage of citric acid.

Fruit TSS/TA ratio was calculated from the values recorded for fruit juice TSS and TA percentages determined.

Total phenolic content (TPC) and total antioxidant activity (TAA) were determined in the methanolic extract $(80 \%)$ of dried guava pulp. TCP was estimated using Folin-Ciocalteu reagent described by Kahkonen et al. (1999). TAA was evaluated on the base of the scavenging activity of the stable 1,1diphenil-2-picrylhydeazyl (DPPH) radical and expressed as $\mathrm{IC}_{50}(\mathrm{mg} / \mathrm{ml})$ which denotes the amount of plant sample extract required to reduce the initial concentration of DPPH radicals by 50\% (Abe et al., 1998;Maswada, 2013).

\section{Shelf life period (days)}

After 24 days of cold storage at $7 \pm 1^{\circ} \mathrm{C}$ a guava fruits samples ( 15 fruit per replicate) was taken out and placed at ambient conditions $\left(22-24^{\circ} \mathrm{C}\right.$ and $65 \pm 5 \%$ RH) till $30 \%$ of fruits became bad appearance or rotting occurs. Then, the number of days was recorded which was considered as shelf life period for guava fruits.

\section{Experimental design and statistical data analysis}

This experiment was arranged in a completely randomized design with three replicates and consisting of two factors; postharvest treatments and storage period. This experiment was analyzed as a factorial experiment. Data calculated as percentage were transformed to arcsine of square root before statistical analysis and non-transformed means are shown as they are. The effects of postharvest treatments and cold storage period on different attributes were 
analyzed statistically by analysis of variance (ANOVA) using the MSTAT-C statistical package. Comparisons between means were done by Duncan's multiple range test (DMRT) at probability $\leq 0.05$.

\section{RESULTS AND DISCUSSION}

With the progress of cold storage period, fruit weight loss and fruit decay percentages were significantly increased while marketable fruit percentage was significantly decreased (Table 1). Moreover, all the postharvest treatments,

Table 1.Effect of postharvest applications of Gum Arabic (GA), Calcium chloride $2 \%\left(\mathrm{CC}_{1}\right)$, Calcium chloride $4 \%\left(\mathrm{CC}_{2}\right)$ and their combinations compared to control (CK) on weight loss, decay and marketable percentages of 'Maamoura' guava fruits during cold storage at $7 \pm 1^{\circ} \mathrm{C}$ and $90 \pm 5 \% \mathrm{RH}$

\begin{tabular}{|c|c|c|c|c|c|c|}
\hline \multirow[t]{2}{*}{ Items } & \multicolumn{2}{|c|}{$\begin{array}{c}\text { Fruit weight loss } \\
(\%)\end{array}$} & \multicolumn{2}{|c|}{$\begin{array}{c}\text { Fruit Decay } \\
(\%)\end{array}$} & \multicolumn{2}{|c|}{$\begin{array}{c}\text { Marketable fruit } \\
(\%)\end{array}$} \\
\hline & 2016 & 2017 & 2016 & 2017 & 2016 & 2017 \\
\hline \multicolumn{7}{|l|}{ Treatments $(T)$} \\
\hline Control & $8.68^{\mathrm{a}}$ & $8.17^{\mathrm{a}}$ & $23.81^{\mathrm{a}}$ & $23.81^{\mathrm{a}}$ & $68.87^{\mathrm{c}}$ & $70.34^{\mathrm{d}}$ \\
\hline GA & $6.29^{\mathrm{bc}}$ & $6.26^{\mathrm{b}}$ & $13.10^{\mathrm{b}}$ & $15.48^{b}$ & $79.94^{\mathrm{b}}$ & $77.81^{\mathrm{cd}}$ \\
\hline $\mathrm{CC}_{1}$ & $7.12^{a b}$ & $7.14^{\mathrm{ab}}$ & $9.52^{\mathrm{bc}}$ & $10.71^{b c}$ & $84.09^{\mathrm{ab}}$ & $81.56^{\text {bc }}$ \\
\hline $\mathrm{CC}_{2}$ & $6.40^{\mathrm{bc}}$ & $6.57^{\mathrm{b}}$ & $7.14^{b-d}$ & $8.33^{b-d}$ & $87.23^{\mathrm{ab}}$ & $86.05^{\mathrm{a}-\mathrm{c}}$ \\
\hline $\mathrm{GA}+\mathrm{CC}_{1}$ & $5.29^{\mathrm{bc}}$ & $4.86^{\mathrm{c}}$ & $3.57^{\mathrm{cd}}$ & $3.57^{\mathrm{cd}}$ & $90.49^{\mathrm{a}}$ & $90.40^{\mathrm{ab}}$ \\
\hline $\mathrm{GA}+\mathrm{CC}_{2}$ & $4.64^{\mathrm{c}}$ & $4.20^{\mathrm{c}}$ & $2.38^{\mathrm{d}}$ & $2.38^{\mathrm{d}}$ & $91.05^{\mathrm{a}}$ & $91.43^{\mathrm{a}}$ \\
\hline \multicolumn{7}{|c|}{ Storage period $($ day $)(S)$} \\
\hline 0 & $0.00^{\mathrm{d}}$ & $0.00^{\mathrm{d}}$ & $0.00^{\mathrm{c}}$ & $0.00^{\mathrm{c}}$ & $100.00^{\mathrm{a}}$ & $100.00^{\mathrm{a}}$ \\
\hline 8 & $5.93^{c}$ & $5.85^{\mathrm{c}}$ & $3.17^{\mathrm{c}}$ & $2.38^{\mathrm{c}}$ & $91.27^{\mathrm{b}}$ & $92.29^{\mathrm{b}}$ \\
\hline 16 & $8.98^{b}$ & $8.26^{\mathrm{b}}$ & $11.90^{\mathrm{b}}$ & $12.70^{\mathrm{b}}$ & $79.26^{\mathrm{c}}$ & $78.13^{c}$ \\
\hline 24 & $10.70^{\mathrm{a}}$ & $10.70^{\mathrm{a}}$ & $24.60^{\mathrm{a}}$ & $27.78^{\mathrm{a}}$ & $63.92^{d}$ & $61.31^{\mathrm{d}}$ \\
\hline $\mathrm{T} * \mathrm{~S}$ significantly & $* *$ & $* *$ & $* *$ & $* *$ & $* *$ & $* *$ \\
\hline
\end{tabular}

Means followed by the same letters within postharvest applications, storage periods and their interactions in each season are not significantly different at level $P \leq 0.05$ according to Duncan's multiple range test.

particularly the combined treatments of GA and 2 or $4 \%$ of $\mathrm{CC}$, reduced the fruit weight loss and fruit decay percentages and gave the highest marketable fruit percentage. Our finding showed that, at 24 days cold storage treated 'Maamoura' 
guava fruits with $\mathrm{GA}+\mathrm{CC}(4 \%)$ scored the lowest decay percentage with better marketable fruits percentage in the two seasons (Table 1).

The water exchange between the internal and external atmosphere is considered the main reason of fruit weight loss and decay percentage and finally led to low marketable percentage during cold storage (Woods, 1990). The increase in transpiration rate, ethylene production and cellular breakdown of fruits resulted in increases in physiological loss of weight and decay incidence as well as a decrease in marketable of guavas with the progress of cold storage (Barman et al., 2011; Razzaq et al., 2014; Abd El-khalek, 2018).

Edible coatings have barrier properties that reduce the surface permeability of fruits to oxygen and carbon dioxide leading to modification of internal gas composition which in turn reduces oxidative metabolism and increases the shelf life of fruits (Dhall, 2013).

Thus, the application of Gum Arabic can reduce the exchange of gases between orange fruits and the environment by the accumulation of carbon dioxide in fruits with low availability of oxygen for respiration and subsequently the inhibition of respiratory enzymes. Moreover, Gum Arabic coating has ability to plug openings present in the peel. Furthermore, coating has the ability to prevent the growth of fungi in wide horticultural products (Tripathi and Dubey, 2004). This application enhanced membrane integrity, delayed fruit senescence and made transpiration and respiration more slower (Laster and Grusak, 2004). Mahajan et al. (2011) reported that postharvest application of $\mathrm{CaCl}_{2}$ extended storage life of guava fruits and reduced spoilage due to its positive role in delaying fruit senescence by maintaining cell wall integrity and reducing decay

Results in Table 2 show that, fruit visual appearance and firmness values were significantly decreased with the advancement of cold storage period at $7^{\circ} \mathrm{C}$ in both seasons. All treatments exceeded the control in increasing visual appearance and firmness values of guava fruits. GA+CC (2\%) and GA+CC (4\%) were the most effective treatments in reducing the reduction in fruit visual appearance and firmness compared to individual applications and the control in both seasons.

The combination of calcium chloride with GA in the present study resulting in delayed the reduction in visual appearance compared to the control treatment. This may due to the film of GA on the surface can protect the fruits from pathogen infection. Fruit firmness is extremely important in overall produce acceptance by the consumers. Guava fruits suffer a rapid loss of 
Table 2. Effect of postharvest applications of Gum Arabic (GA), Calcium chloride $2 \%\left(\mathrm{CC}_{1}\right)$, Calcium chloride $4 \%\left(\mathrm{CC}_{2}\right)$ and their combinations compared to control $(\mathrm{CK})$ on fruit appearance and firmness of 'Maamoura' guava fruits during cold storage at $7 \pm 1^{\circ} \mathrm{C}$ and $90 \pm 5 \% \mathrm{RH}$

\begin{tabular}{|c|c|c|c|c|}
\hline \multirow[t]{2}{*}{ Items } & \multicolumn{2}{|c|}{$\begin{array}{c}\text { Fruit appearance } \\
(1-9)\end{array}$} & \multicolumn{2}{|c|}{$\begin{array}{l}\text { Firmness } \\
(\mathbf{N})\end{array}$} \\
\hline & 2016 & 2017 & 2016 & 2017 \\
\hline \multicolumn{5}{|l|}{ Treatments $(T)$} \\
\hline Control & $6.33^{\mathrm{d}}$ & $5.58^{\mathrm{e}}$ & $25.29^{\mathrm{e}}$ & $20.76^{\mathrm{e}}$ \\
\hline GA & $7.58^{c}$ & $7.33^{\mathrm{d}}$ & $41.23^{\mathrm{d}}$ & $36.98^{d}$ \\
\hline $\mathrm{CC}_{1}$ & $7.92^{b c}$ & $7.83^{\mathrm{cd}}$ & $44.91^{\mathrm{cd}}$ & $39.06^{\mathrm{cd}}$ \\
\hline $\mathrm{CC}_{2}$ & $8.25^{\mathrm{ab}}$ & $8.00^{\mathrm{bc}}$ & $49.32^{\mathrm{bc}}$ & $42.09^{\mathrm{bc}}$ \\
\hline $\mathrm{GA}+\mathrm{CC}_{1}$ & $8.58^{\mathrm{a}}$ & $8.50^{\mathrm{ab}}$ & $53.16^{\mathrm{ab}}$ & $44.95^{\mathrm{ab}}$ \\
\hline $\mathrm{GA}+\mathrm{CC}_{2}$ & $8.83^{\mathrm{a}}$ & $8.83^{\mathrm{a}}$ & $56.18^{\mathrm{a}}$ & $47.89^{\mathrm{a}}$ \\
\hline \multicolumn{5}{|c|}{ Storage period (day) $(S)$} \\
\hline 0 & $9.00^{\mathrm{a}}$ & $9.00^{\mathrm{a}}$ & $67.67^{\mathrm{a}}$ & $58.84^{\mathrm{a}}$ \\
\hline 8 & $8.78^{\mathrm{a}}$ & $8.50^{b}$ & $51.35^{\mathrm{b}}$ & $42.01^{\mathrm{b}}$ \\
\hline 16 & $8.00^{b}$ & $7.67^{\mathrm{c}}$ & $36.53^{c}$ & $32.44^{\mathrm{c}}$ \\
\hline 24 & $5.89^{c}$ & $5.56^{\mathrm{d}}$ & $24.52^{d}$ & $21.19^{\mathrm{d}}$ \\
\hline $\mathrm{T} * \mathrm{~S}$ significantly & $*$ & $*$ & $* *$ & $* *$ \\
\hline
\end{tabular}

Means followed by the same letters within postharvest applications, storage periods and their interactions in each season are not significantly different at level $P \leq 0.05$ according to Duncan's multiple range test.

firmness after harvest, which contributes greatly to its short postharvest life and susceptibility to fungal contamination (Reyes and Paul, 1995). The loss of fruit firmness starts with the conversion of insoluble protopectin into water soluble pectin by breakdown of the middle lamellae, which is intimately related to hydrolytic enzyme, so rigidity of cell walls would be reduced and leading to fruit softening (Payasi et al., 2009). The reduction in flesh firmness of guavas with the progress of cold storage could be attributed to the increase in the activities of cell wall hydrolysis enzymes and the degradation of cellular structures accompanied with the increases in ethylene production and respiration rate (Reyes and Paul, 1995; Jain et al., 2003; Mondal, 2005). Our findings indicated that edible coatings with calcium chloride at concentration of 2 or $4 \%$ in addition 
to Gum Arabic increase fruit firmness as compared to the control treatment. A similar trend in the results was revealed by Oms-Oliu et al. (2008) and Abd Elkhalek (2018), who reported that coating of fruits with Gum Arabic retains firmness for longer time and acts as a barrier to avoid loss of nutrients and water. Fruit softening occurred due to deterioration of cell structure, composition and degradation of intracellular material (Seymour et al., 1993).

During the process of ripening, the chain length of pectin material is shortened which ultimately increased the pectin esterase and polygalacturonase activities (Yaman and Bayiondirli, 2002). Firmness of fruit is closely associated to less availability of oxygen and higher availability of carbon dioxide that inhibit enzymatic activities during the entire storage life (Rojas-Grau et al., 2009). Moreover, the positive effect of calcium chloride on fruit firmness might be attributed to the possible role of calcium ions in the bridging of anti-parallel pectic polysaccharide homogalacturonan, which plays a vital role in maintaining cell wall integrity and cell-wall cohesion, with negatively charged carboxyl groups. The positive effect of calcium may also be explained by its role in reducing the accessibility of cell wall-degrading enzymes to cell wall component substrates (Vicente et al., 2009). In this regard, it is worth mentioning that Akhtar et al. (2010) and Gupta et al.(2011) reported that higher calcium chloride concentrations retained firmness more than its lower concentrations.

Data in Fig.1 declared that, 'Maamoura' guavas color changes from yellowish green to yellow with increased of cold storage period at $7{ }^{\circ} \mathrm{C}$ in the two seasons as indicated by decreased total chlorophyll (Fig.1A) and increased total carotenoids (Fig.1B). The loss of chlorophyll content during cold storage could be attributed to the breakdown of the chlorophyll structure and increases in chlorophyllase enzyme activity. After chlorophyll degradation, yellow carotenoid pigments become visible (Wills et al., 1998). On the other hand, all postharvest applications, GA, CC and their combinations delayed color development of guava fruits during cold storage periods and significantly retained total chlorophyll content. The combination treatments achieved higher total chlorophyll content compared with individual treatments and control (Fig.1A). While, the maximum carotenoids content was obtained by individual treatments of GA and calcium chloride (Fig.1B). Calcium chloride delayed the colour development might be resulted from the role of calcium in decreasing the biosynthesis of carotenoids, anthocyanin, and preservation of chlorophyll content. The same result was reported by Moradinezhad and Jahani (2016). 
USAMA EL-ABBASY et al.

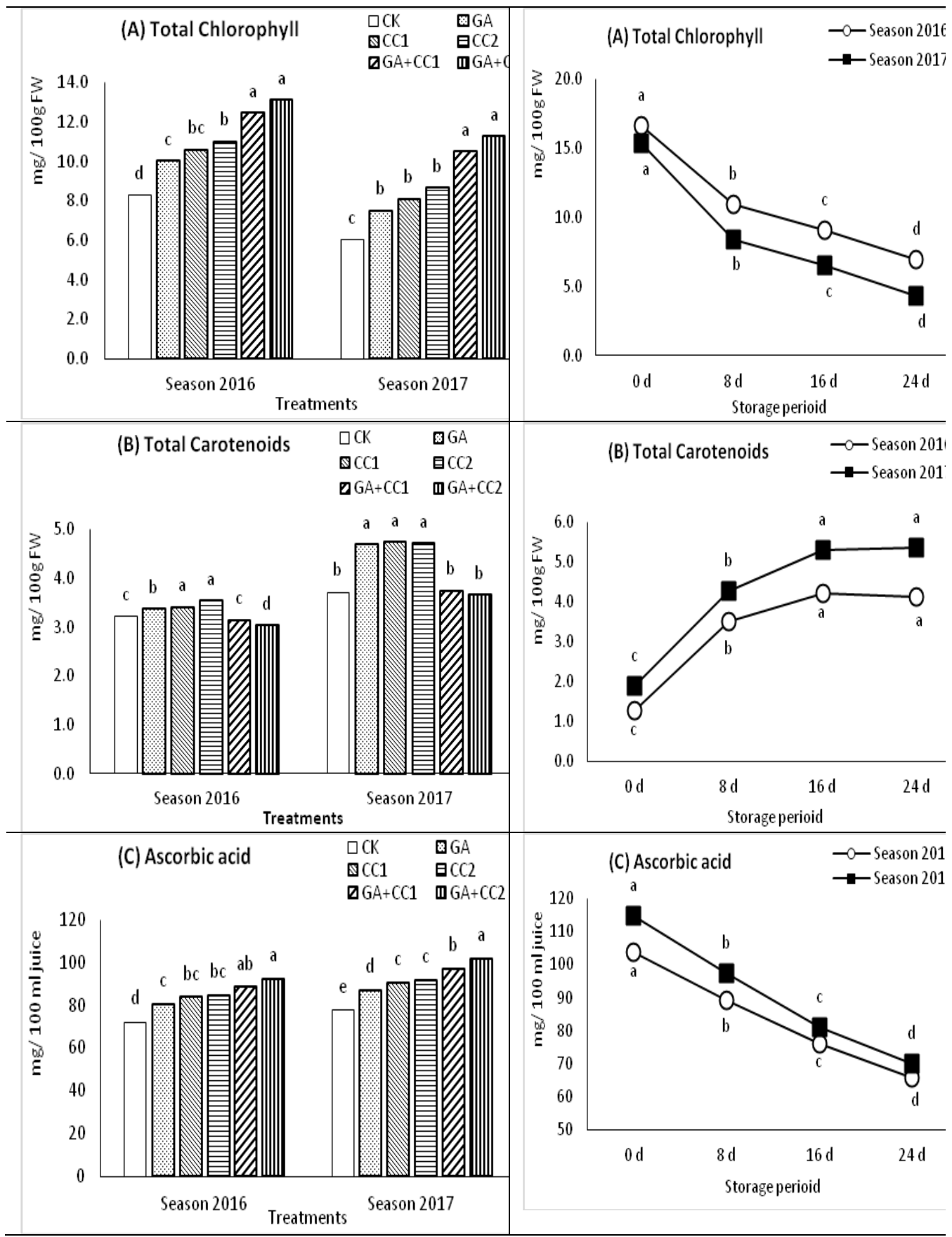


Fig. 1. Effect of postharvest applications of Gum Arabic (GA), Calcium chloride 2\% $\left(\mathrm{CC}_{1}\right)$, Calcium chloride $4 \%\left(\mathrm{CC}_{2}\right)$ and their combinations compared to control (CK) on the concentration of (A) total chlorophyll, (B) carotenoids and (C) ascorbic acid of 'Maamoura' guava fruits (right) during different cold storage periods (left) at $7 \pm 1^{\circ} \mathrm{C}$ and $90 \pm 5 \% \mathrm{RH}$.

Means followed by the same letters within postharvest applications, storage periods and their interactions in each season are not significantly different at level $P \leq 0.05$ according to Duncan's multiple range test.

As shown in Fig. $1 \mathrm{C}$, ascorbic acid (AsA) was decreased with the increase of storage period where it reached the lowest values at the end of storage (24 days). The loss of ascorbic acid content of guavas fruits during cold storage period might be due to a rapid conversion of L-ascorbic acid into dehydro-ascorbic acid in the presence of oxidizing enzymes like ascorbic acid oxidase and ascorbate peroxidase (Davey et al., 2000) .Moreover, the combined treatments, particularly $\mathrm{GA}+\mathrm{CC}(4 \%)$, were more effective in maintaining AsA content of fruits as compared with individual treatment in both seasons. Coating modifies the atmosphere and inhibits gaseous exchange which prevents ascorbic acid oxidation by reducing the entry of oxygen to interior parts of the fruit (Baldwin et al., 1999). The findings of Akhtar et al.(2010) were also in the line as of ours and described that calcium chloride treated loquat contained higher amount of ascorbic acid as compared to non-treated fruits. Gradual decrease in ascorbic acid content was observed during storage period. Ruoyi et al. (2005) described that, postharvest application of $\mathrm{CaCl}_{2}$ at $0.5 \%$ maintained the amount ascorbic acid in peaches fruits till fifty days. Calcium chloride treatments resulted in higher ascorbic acid concentrations compared with the control fruits at the end of the storage period. These findings are in agreement with the results reported earlier for apples (El-Anany et al., 2009), guavas (Mahajan et al., 2011), and oranges (Abd El-khalek, 2018).

Total soluble solids (TSS) content of 'Maamoura' guava fruits was significantly increased with increasing cold storage periods, and reached to maximum values at 16 days of cold storage, and then decreased. In contrast, titratable acidity (TA) of guava fruits was sharply reduced with increasing storage period where it reached the lowest values under the end of storage. While, TSS/TA ratio significantly increased with the increase of cold storage period in both seasons (Table 3). TA is directly related to the concentration of 
Table 3. Effect of postharvest applications of Gum Arabic (GA), Calcium chloride $2 \%\left(\mathrm{CC}_{1}\right)$, Calcium chloride $4 \%\left(\mathrm{CC}_{2}\right)$ and their combinations compared to control (CK) on total soluble solids (TSS) ( ${ }^{\circ}$ Brix), titratable acidity (TA, \%) and TSS/TA ratio of 'Maamoura' guava fruits during cold storage at $7 \pm 1^{\circ} \mathrm{C}$ and $90 \pm 5 \% \mathrm{RH}$

\begin{tabular}{|c|c|c|c|c|c|c|}
\hline \multirow[t]{2}{*}{ Items } & \multicolumn{2}{|c|}{$\begin{array}{c}\text { TSS } \\
\left({ }^{\circ} \text { Brix }\right) \\
\end{array}$} & \multicolumn{2}{|c|}{$\begin{array}{l}\text { TA } \\
(\%)\end{array}$} & \multicolumn{2}{|c|}{$\begin{array}{c}\text { TSS/TA } \\
\text { ratio } \\
\end{array}$} \\
\hline & 2016 & 2017 & 2016 & 2017 & 2016 & 2017 \\
\hline \multicolumn{7}{|l|}{ Treatments $(T)$} \\
\hline Control & $8.85^{\mathrm{a}}$ & $9.08^{\mathrm{a}}$ & $0.65^{\mathrm{c}}$ & $0.61^{\mathrm{e}}$ & $18.91^{\mathrm{a}}$ & $20.81^{\mathrm{a}}$ \\
\hline GA & $8.75^{\mathrm{ab}}$ & $8.96^{\mathrm{ab}}$ & $0.68^{\mathrm{bc}}$ & $0.65^{\mathrm{de}}$ & $17.14^{\mathrm{ab}}$ & $18.23^{b}$ \\
\hline $\mathrm{CC}_{1}$ & $8.72^{a b}$ & $8.89^{a-c}$ & $0.71^{\mathrm{bc}}$ & $0.69^{\mathrm{cd}}$ & $15.57^{\mathrm{bc}}$ & $16.48^{\mathrm{bc}}$ \\
\hline $\mathrm{CC}_{2}$ & $8.68^{a b}$ & $8.84^{\mathrm{bc}}$ & $0.76^{\mathrm{b}}$ & $0.74^{\mathrm{bc}}$ & $13.89^{c}$ & $14.58^{\mathrm{cd}}$ \\
\hline $\mathrm{GA}+\mathrm{CC}_{1}$ & $8.59^{\mathrm{bc}}$ & $8.74^{c}$ & $0.87^{\mathrm{a}}$ & $0.79^{\mathrm{ab}}$ & $11.19^{\mathrm{d}}$ & $12.72^{\mathrm{de}}$ \\
\hline $\mathrm{GA}+\mathrm{CC}_{2}$ & $8.46^{c}$ & $8.73^{\mathrm{c}}$ & $0.94^{\mathrm{a}}$ & $0.83^{\mathrm{a}}$ & $9.53^{d}$ & $11.51^{\mathrm{e}}$ \\
\hline \multicolumn{7}{|l|}{$\begin{array}{l}\text { Storage period } \\
(\text { day })(S)\end{array}$} \\
\hline 0 & $6.47^{\mathrm{d}}$ & $6.80^{\mathrm{d}}$ & $1.12^{\mathrm{a}}$ & $1.07^{\mathrm{a}}$ & $5.79^{d}$ & $6.40^{\mathrm{d}}$ \\
\hline 8 & $7.73^{\mathrm{c}}$ & $7.98^{c}$ & $0.85^{\mathrm{b}}$ & $0.83^{\mathrm{b}}$ & $9.29^{c}$ & $9.87^{\mathrm{c}}$ \\
\hline 16 & $10.45^{\mathrm{a}}$ & $10.65^{\mathrm{a}}$ & $0.63^{\mathrm{c}}$ & $0.55^{\mathrm{c}}$ & $18.35^{\mathrm{b}}$ & $20.77^{\mathrm{b}}$ \\
\hline 24 & $10.06^{\mathrm{b}}$ & $10.0^{\mathrm{b}}$ & $0.48^{\mathrm{d}}$ & $0.42^{\mathrm{d}}$ & $24.06^{\mathrm{a}}$ & $25.86^{\mathrm{a}}$ \\
\hline $\mathrm{T} * \mathrm{~S}$ significantly & $* *$ & $* *$ & $* *$ & $* *$ & $* *$ & $* *$ \\
\hline
\end{tabular}

Means followed by the same letters within postharvest applications, storage periods and their interactions in each season are not significantly different at level $P \leq 0.05$ according to Duncan's multiple range test.

organic acids present in the fruit. Citric acid is the major organic acid in guava fruits, which is an important parameter in maintaining the quality of fruits and rapid reduction in acidity hastens senescence of fruits (Jain et al., 2003). The progressive decline of guavas content in TA with the advancement of storage period might be due to utilization of organic acids in respiration process and conversion of acids into salts and sugars by the enzymes (Jain et al., 2003). On the other hand, the increase in guavas fruits content in TSS with prolonging of storage period could be attributed to the hydrolysis of starch into sugars and an increase in water soluble galacturonic acids from the degradation of pectic substances by hydrolytic enzymes (Jain et al., 2003). Whereas, slight decline of fruits content in TSS at the end of storage period might be due to utilization of soluble solids in respiratory processes (Jain et al., 2003). All postharvest applications (GA, CC and their combinations) significantly increased TA (\%) in 


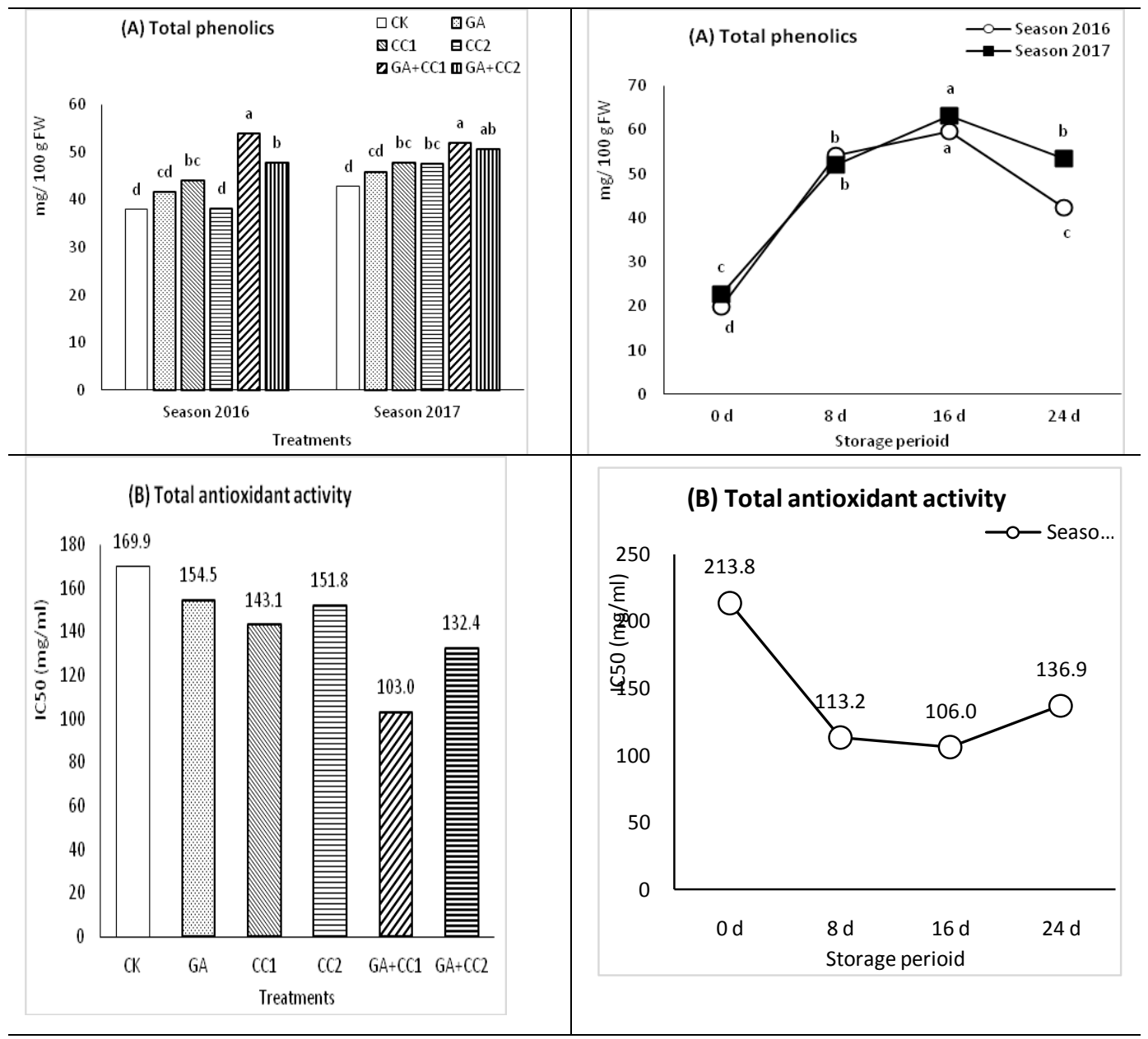

Fig. 2. Effect of postharvest applications of Gum Arabic (GA), Calcium chloride 2\% $\left(\mathrm{CC}_{1}\right)$, Calcium chloride $4 \%\left(\mathrm{CC}_{2}\right)$ and their combinations compared to control (CK) on (A) total phenolic content and (B) total antioxidant activity indicated by $\mathrm{IC}_{50}$ of 'Maamoura' guava fruits (right) during different cold storage periods (left) at $7 \pm 1^{\circ} \mathrm{C}$ and $90 \pm 5 \% \mathrm{RH}$.

Means followed by the same letters within postharvest applications, storage periods and their interactions in each season are not significantly different at level $P \leq 0.05$ according to Duncan's multiple range test. 
guava fruits compared to control. Opposite trend was observed in case of TSS content and TSS/TA ratio. In both seasons, treated "Maamoura' guavas friuts with $\mathrm{GA}+\mathrm{CC}_{2}(4 \%)$ showed the lowest fruits contents of TSS and TSS/TA ratio and the highest fruit contents of TA (Table 3). Echeverria and Ismail(1987) reported that, the lower values of TSS in treated samples as compared with control might be due to the conversion of organic acids to sugars through gluconeogenesis, and the solubilization of cell wall constituents by galactosidases and glucosidases present in guava fruit. Moreover, TA retention in calcium chloride treated fruits might be due to decreased hydrolysis of organic acids and subsequent accumulation of these acids, which are oxidized at a slower rate because of decreased respiration (Gupta et al., 2011).

Results in Fig. 2(A) demonstrated that, total phenolics (TP) content of 'Maamoura' guava fruits was significantly increased with increasing cold storage periods, and reached its maximum value at 16 days of cold storage, and then decreased at 24 days.

The same trend was seen in total antioxidant activity (TAA) as indicated by $\mathrm{IC}_{50}$ values (Fig. 2B). $\mathrm{IC}_{50}$ values is inversely related to TAA (Maswada, 2013), where the lower IC $_{50}$ values indicated the higher TAA. Furthermore, TP and TAA were more pronounced owing to the combined treatments of postharvest applications compared with individual treatments and control. The maximum TP and TAA (the lowest $\mathrm{IC}_{50}$ ) were recorded in guava fruits dipped in $\mathrm{GA}+\mathrm{CC}_{1}(2 \%)$ followed by $\mathrm{GA}+\mathrm{CC}_{2}(4 \%)$. Phenolic compounds possess antioxidant properties and serve as protective mechanisms in fruits. TP content has a defense mechanism against the invasion of plant pathogens and playing an important role in plant resistance (Beckman, 2000). Moreover, the presence of antioxidants and phenols could be substantially reduced the reactive oxygen species (ROS) and prevented lipid peroxidation of plant tissue by trapping the lipid alkoxyl radical (Blokhina et al., 2003). Maintaining TP and enhancing TAA could be ascribed to ability of postharvest treatments for scavenging the excess ROS and consequently reducing the oxidative damage of the fruits (Reena, 2016; Khaliq et al., 2016). Therefore, these treatments delayed the senescence process of fruits as compared to control. Previously, a positive correlation among TP and TAA has also been reported in some medicinal plants (Maswada, 2013), mangoes (Khaliq et al., 2016) and oranges (Abd El-khalek, 2018). Therefore, in our study, the maximum amount of TP in treated than 
Table 4. Effect of postharvest applications of Gum Arabic (GA), Calcium chloride $2 \% \quad\left(\mathrm{CC}_{1}\right)$, Calcium chloride $4 \%\left(\mathrm{CC}_{2}\right)$ and their combinations compared to control (CK) on fruit shelf life of 'Maamoura' guava fruits after cold storage in the normal atmosphere of the room temperature) $\left(22-24^{\circ} \mathrm{C}\right)$

\begin{tabular}{lrrrr}
\hline \multirow{2}{*}{ Treatments } & \multicolumn{5}{c}{ shelf life (day) } \\
\cline { 2 - 5 } & \multicolumn{5}{c}{$\mathbf{2 0 1 6}$} & $\mathbf{2 0 1 7}$ & \\
\hline Control & 1.67 & $\mathrm{c}$ & 2.33 & $\mathrm{c}$ \\
$\mathrm{GA}$ & 5.67 & $\mathrm{~b}$ & 5.67 & $\mathrm{~b}$ \\
$\mathrm{CC}_{1}$ & 4.67 & $\mathrm{~b}$ & 5.33 & $\mathrm{~b}$ \\
$\mathrm{CC}_{2}$ & 5.67 & $\mathrm{~b}$ & 5.67 & $\mathrm{~b}$ \\
$\mathrm{GA}+\mathrm{CC}_{1}$ & 8.67 & $\mathrm{a}$ & 8.00 & $\mathrm{a}$ \\
$\mathrm{GA}+\mathrm{CC}_{2}$ & 9.34 & $\mathrm{a}$ & 8.67 & $\mathrm{a}$ \\
\hline
\end{tabular}

Means followed by the same letters within postharvest applications, storage periods and their interactions in each season are not significantly different at level $P \leq 0.05$ according to Duncan's multiple range test.

uncoated fruits, which means that treated fruit enhanced the resistance of plant tissues to pathogens and reducing their physiological deterioration.

Finally, the extended of fruit shelf life was more superior due to the combined treatments of GA and CC (4\% and 2\%) than individual treatments and control (Table 4). Özden and Bayindirli (2002) reported that shelf life of guava fruit can be enhanced significantly by the application of calcium salts.

\section{CONCLUSION}

In general, our results showed positive influence of both postharvest applications and their combinations on maintaining quality attributes of 'Maamoura' guavas during cold storage. The combined treatments of Gum Arabic with calcium chloride 2 and $4 \%$ were the most effective coating for Guava fruit fresh under long period of cold storage. These applications significantly decreased physiological loss in weight and reduced decay incidence, as well as, maximized marketable percentage, maintained visual appearance score and retarded fruit softening during cold storage period at $7^{\circ} \mathrm{C}$.

Moreover, these applications delayed colour development by significantly retained total chlorophyll content and maintained fruit contents in vitamin $\mathrm{C}$ and titratable acidity as well as slowed the accumulation of fruit contents in total soluble solids and total soluble solids/ titratable acidity ratio than untreated fruits 
(control) during cold storage period. Ultimately, these applications significantly prolonged shelf life period at ambient conditions $\left(25 \pm 2^{\circ} \mathrm{C}\right.$ and $\left.65 \pm 5 \% \mathrm{RH}\right)$ after end of cold storage period (24 days) as compared to control.

\section{REFERENCES}

Abd El-khalek, A.F. (2018). Effectiveness of gum arabic, potassium salts and their incorporation in the control of postharvest diseases and maintaining quality of 'Washington' navel oranges during long term cold storage. Egyptian Journal of Horticulture, 45 (2): 185-203.

Abe, N.; T. Murata and A. Hirota (1998). Novel DPPH radical scavengers, bisorbicillinol and dimethytrichodimerol, from a fungus.Bioscience, Biotechnology and Biochemistry, 62: 661-666.

Akhtar,A.; N.A. Abbasi and A. Hussain (2010). Effect of Calcium chloride treatment on quality characteristics of loquat fruit during storage. Pakistan Journal of Botany, 42:181-188.

AOAC (2005). Official Method of Analysis of Association of Official Analytical Chemist International. 18 ${ }^{\text {th }}$ Edition. North Frederick Avenue, Gaithersburg, Maryland, USA.

Baldwin, E.A.; J.K. Burns; W. Kazokas; J.K. Brecht; R.D. Hagenmaier; R.J. Bender and E. Pesis (1999). Effect of two edible coatings with different permeability characteristics on mango (Mangifera indicaL.) ripening during storage. Postharvest Biology and Technology, 17: 215-226.

Barman, K.; A. Ram and R. K. Pal (2011). Putrescine and carnauba wax pretreatments alleviate chilling injury, enhance shelf life and preserve pomegranate fruit quality during cold storage. Scientia Horticulturae, 130:795-800.

Beckman, C.H. (2000). Phenolic-storing cells: key to programmed cell death and periderm formation in wilt disease resistance and in general defense response in plants. Physiological and Molecular Plant Pathology,57: 101-110.

Blokhina, O.; Virolainen, E. and K.V.Fagerstedt (2003) Antioxidants, oxidative damage and oxygen deprivation stress: a review. Annals of Botany,91: 179-194. 
Chardonnet, C.O.; C.S. Charron; C.E. Sams and W.S. Conway (2003). Chemical changes in the cortical tissue and cell walls of calcium infiltrated Golden Delicious' apple during storage". Postharvest Biology and Technology,28: 97-111.

Davey, M.W.; M.Van Montagu;D. Inze; M. Sanmartin; A. Kanellis and N. Smirnoff (2000). Plant L-ascorbic acid: chemistry, function, metabolism, bioavailability and effects of processing. Journal of Science Food and Agriculture, 80: 825-860.

Dhall, R.K. (2013). Advances in edible coatings for fresh fruits and vegetables: a review. Critical Reviews in Food Science and Nutrition, 53 (5): 435-450.

Echeverria, E. and M. Ismail (1987). Changes in sugars and acids of citrus fruits during storage. Proceedings of the Florida State".. Horticultural Society, 100: 50-52.

El-Anany, A.M.; G.F.A. Hassan and Rehab F.M. Ali (2009). Effects of edible coatings on the shelf-life and quality of Anna apple (Malus domestica Borkh.) during cold storage. Journal of Food Technology, 7: 5-11.

Falcao-Rodrigues, M.M.; M. Maldao-Martins and L.B.D. Costa (2007). DSC as a tool to assess physiological evolution of apples preserved by edible coatings. Food Chemistry, 102: 475-480.

FAO, Statistics (2017). Food and Agriculture Organization of the United Nation.

Gupta, N.; S.K. Jawandhaand S.P.Gill (2011). Effect of calcium on cold storage and post cold storage quality of peach. Journal of Food Science andTechnology, 48: 225-229.

Hui, Y.H. (2004). Handbook of Fruits and Fruit Processing. Blackwell Pub. Co., Iowa, USA.

Jain, N.; K.Dhawan; S. Malhotraand R. Singh (2003). Biochemistry of fruit ripening in guava (Psidium guajava L.) compositional and enzymatic changes. Plant Foods for Human Nutrition,58: 309-315.

Jilani, M.S.; F. Bibi; K. Waseem and M.A. Khan (2010). Evaluation of physico-chemical characteristics of mango (Mangifera indicaL.) cultivars grown in D.I. Khan. Journal of Agriculture Research, 48:201-207.

Kahkonen, M.P.; A.I. Hopia; H.J. Vuorela; J.P. Rauha; K. Pihlaja; T.S.Kujala and M. Heinonen (1999). Antioxidant activity of plant extracts containing phenolic compounds. Journal of Agricultural and Food Chemistry,47: 3954-3962. 
Khaliq, G.;M.T.M. Mohammad;P. Ding; H.M. Ghazali and A. Ali (2015). Effect of gum arabic coating combined with calcium chloride on physicochemical and qualitative properties of mango (Mangifera indica L.) fruit during low temperature storage. Scientia Horticulturae, 190: 187-194.

Khaliq, G., M.T.M. Mohamed; A. B. Hasanah and A. Ali (2016). Influence of gum arabic coating enriched with calcium chloride on physiological, biochemical and quality responses of mango (Mangifera indica L.) fruit stored under low temperature stress. Postharvest Biology and Technology, 3: 362- 369.

Laster, G.E. and M.A. Grusak (2004). Field application of chelated calcium: Post-harvest effects on cantaloupe and honeydew fruit quality. Horticulture Technology, 14: 2-38.

Mahajan, B.V.C.;B.S. Ghuman, andH.K. Bons (2011). Effect of postharvest treatments of calcium chloride and gibberellic acid on storage behaviour and quality of guava fruits. Journal of Horticultural Science and Ornamental Plants, 3:38-42.

Maqbool, M.; A. Ali; P.G. Alderson;N. Zahidand Y. Siddiqui (2011). Effect of a novel edible composite coating based on gum arabic and chitosan on biochemical and physiological responses of banana fruits during cold storage. Journal of Agricultural and Food Chemistry 59: 5474-5482.

Maswada, H.F. (2013). Evaluation of antioxidants and free radical scavenging activity of three Egyptian geophytic species. Journal of Medical Science, 13(7):546-554.

Mercado-Silva, E.; P. Benito-Bautista and M.A. Garcia-Velasco (1998). Fruit development, harvest index and ripening changes of guavas produced in central Mexico. Postharvest Biology and Technology, 13: 143-150.

Mondal, K. (2005). Antagonistic effect of polyamines on ripening related biochemical changes in guava (Psidium guajavaL.). Ph.D Thesis. Department of Biochemistry, CCS Haryana Agricultural University, Hisar, India.

Moradinezhad, F. and M. Jahani (2016): Quality improvement and shelf life extension of fresh apricot fruit (Prunus Armeniaca cv. Shahroudi) using postharvest chemical treatments and packaging during cold storage. International Journal of Horticultural Science and Technology,3(1): 9-18. 
Oms-Oliu, G.; R. Soliva-Fortuny and O.M. Belloso(2008). Edible coatings with antibrowning agents to maintain sensory quality and antioxidant properties of fresh-cut pear. Postharvest Biology and Technology, 50: 87-94.

Özden, C. and L. Bayindirli (2002). Effects of combinational use of controlled atmosphere, cold storage and edible coating applications on shelf life and quality attributes of apples. European Food Research Technology, 21(4): 320-326.

Payasi, A.;N.N. Mishra; A.L.S. Chavesand R. Singh (2009). Biochemistry of fruit softening: an overview. Physiology and Molecular Biology of Plants, 15: 103-113.

Razzaq, K.; A.S. Khan;A.U. Malik; M. Shahidand S. Ullah (2014). Role of putrescine in regulating fruit softening and antioxidative enzyme systems in 'Samar Bahisht Chaunsa' mango. Postharvest Biology and Technology, 96:23-32.

Reena, D.M.S.R. (2016). Role of gibberellic acid and calcium chloride in ripening related biochemical changes in guava (Psidium guajava L.) fruit. Ph.D. Thesis.Department of Chemistry and Biochemistry, College of Basic Science and Humanities CCS, Haryana Agricultural University, Hisar-125 004, India.

Reyes, M.U. and R.E. Paul (1995). Effects of storage temperature and ethylene treatments of guava (Psidium guajava L.) fruit ripening. Postharvest Biology and Technology,6: 357-365.

Rojas-Grau, M.A.; M.S. Tapia and O. Martin-Belloso (2009). Using polysaccharide-based edible coatings to maintain quality of fresh-cut Fuji apples. LWT, 41: 139-147.

Ruoyi, K.; Y. Zhifang and L.Z. Zhaoxin (2005). Effect of coating and intermittent warming on enzymes, soluble pectin substances and ascorbic acid of Prunuspersica (cv. Zhonghuashoutao) during refrigerated storage. Food Research International, 38(3): 331-336.

Seymour, G.B.; J.E. Taylor and G.A. Tucker (1993). Biochemistry of fruit ripening. London, UK: Chapman and Hall.

Tripathi, P. and N.K. Dubey (2004). Exploitation of natural products as an alternative strategy to control postharvest fungal rotting of fruit and vegetables. Postharvest Biology and Technology, 32: 235-245. 
Vicente, A.R.; G.A. Manganaris; G.O.Sozziand C.H. Crisosto (2009). Nutritional quality of fruits and vegetables. In: Postharvest Handling: A Systems Approach. W.J. Florkowski, R.L. Shewfelt, B. Brueckner, S.E. Prussia (Eds), Elsevier Inc.- Academic Press, San Diego, 57-106.

Watkins, C. and J. Harman (1981). Use of penetrometer to measure flesh firmness of fruit. Orchadist, N.Z., 14-16.

Wellburn, A.R. (1994). The spectral determination of chlorophylls $a$ and $b$, as well as total carotenoids, using various solvents with spectrophotometers of different resolution. Journal of Plant Physiology, 144: 307-313.

Wills, R.H.; B. McGlasson; D. Grahamand D. Joyce (1998). Postharvest: an introduction to the physiology and handling of fruit, vegetables and ornamentals. ( $4^{\text {th }}$ Edition). CAP International, Wallingford Oxen 108DE, UK., 4, 262 p.

Woods, J.L. (1990). Moisture loss from fruits and vegetables. Postharvest news and information, 1 (3): 195-199.

Yaman, O. and L. Bayiondirli (2002). Effect of an edible coating storage on shelf-life and quality of cherries. Lebensm-Wiss. Und-Technol. 35:146-150.
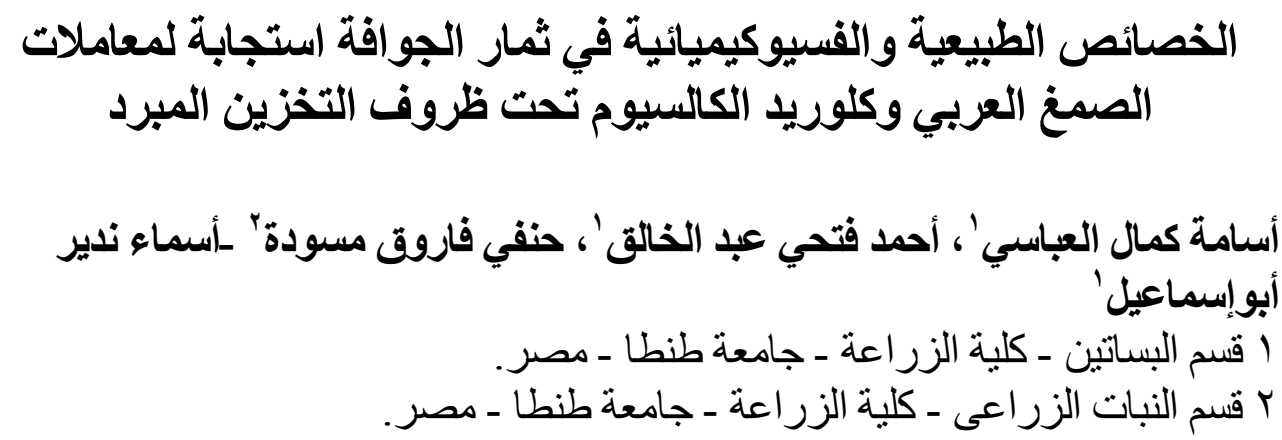

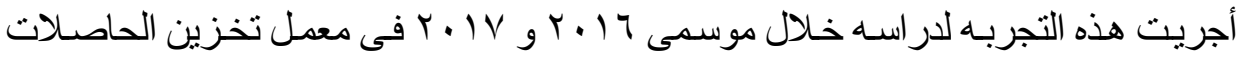

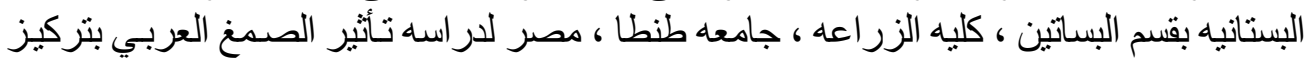

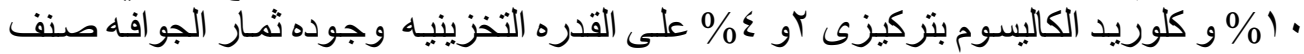

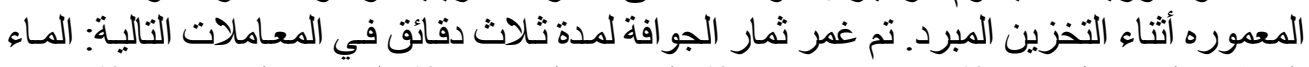

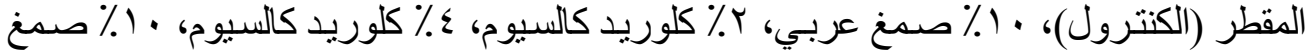

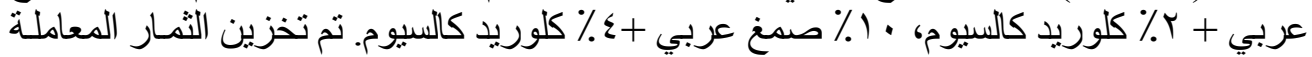




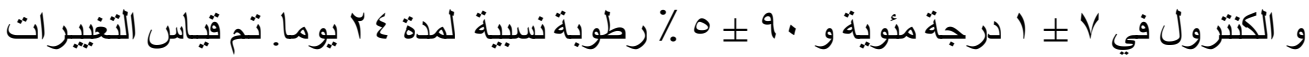
في الخصائص الفيزيائية والكيميائية لثمار الجو افة كل ثمانية أيام من التخزين المبرد.

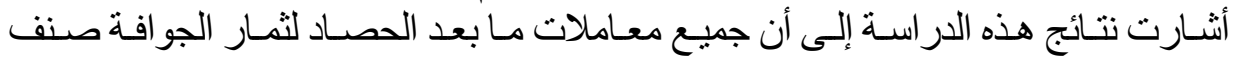

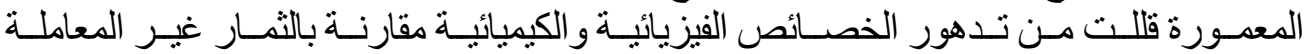

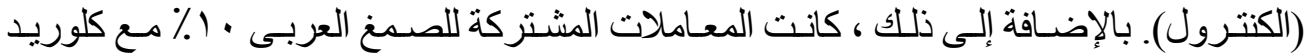

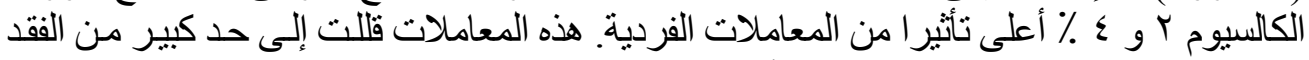

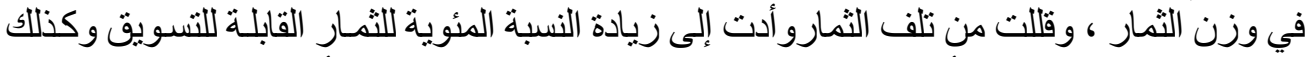

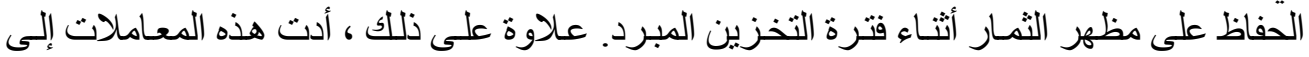

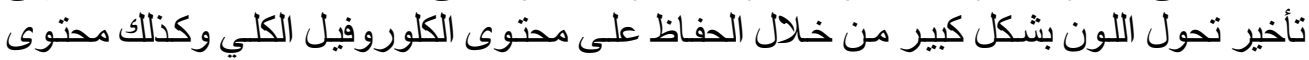

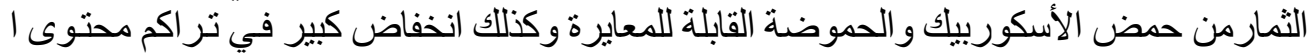

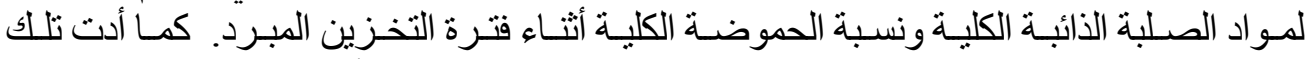

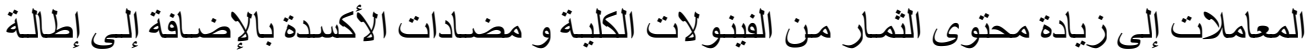

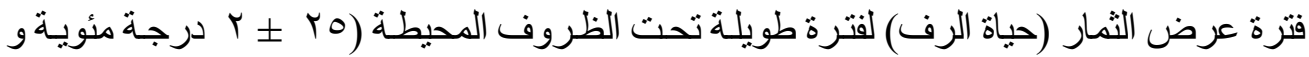
RH \% 0 × 0

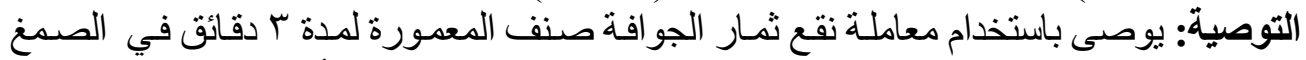

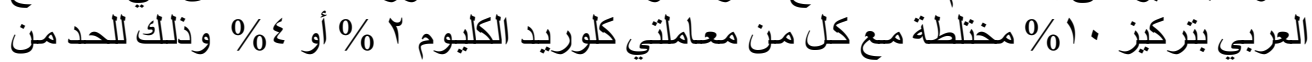

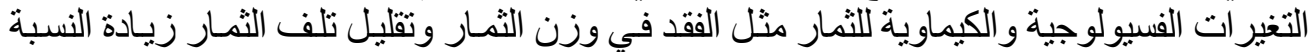
المئوية للثمار القابلة للتسويق وكذللك الحفاظ على مظهر الثمار أثناء فترة التخزين المبرد. 